\title{
BIRTH WEIGHT OF INFANTS BORN TO IMMIGRANT WOMEN
}

BY

\author{
S. L. BARRON* \\ St. Thomas' and Lambeth Hospitals \\ AND \\ M. P. VESSEY $†$ \\ Rothamsted Experimental Station
}

The first scientific study of human birth weight appears to have been made by the German obstetrician Roederer in 1753 (Cone, 1961), since which time an extensive literature has accumulated. The important factors which have been shown to be correlated with birth weight are summarized in Table I.

There have, however, been relatively few comparative studies of the birth weights of infants from different ethnic groups and most of these have compared samples of different socio-economic status. In their review of the literature, Hytten and Leitch (1964) concluded that Indian infants were lighter at birth when compared with Caucasians, Bantu, and other coloured groups in South Africa (Salber and

* Now Consultant Obstetrician and Gynaecologist, Tottenham and Hackney Hospital Groups.

† Present Address: Statistical Research Unit, (M.R.C.) University College Hospital Medical School, London.
Bradshaw, 1951); with Chinese and Malayans in Malaya (Llewellyn-Jones, 1955); with Africans in Kenya (Shaw, 1933) and in India when compared with other races in general (e.g. Rajoo and Naidu, 1944; Achar and Yankauer, 1962). Other studies show that, whereas the Chinese infant born in China is on the average much lighter than the European infant (e.g. Uttley, 1940; Lee, 1948), the difference is much less marked when well-fed Chinese and Europeans in Hawaii are compared (Connor, Bennett, and Louis, 1957).

Meredith (1952) found American Negroes to have a lower birth weight than Caucasians and this finding has recently been confirmed by a large-scale study in New York by Erhardt, Joshi, Nelson, Kroll, and Weiner (1964).

As a result of immigration, it is now possible to compare different nationality groups in Britain. At

TABLE I

FACTORS CORRELATED WITH BIRTH WEIGHT

\begin{tabular}{|c|c|c|c|}
\hline \multirow{2}{*}{ Factor } & \multirow{2}{*}{ Correlation with Birth Weight } & \multicolumn{2}{|c|}{ Example Reference } \\
\hline & & Authors & Date \\
\hline Duration of Gestation & Positive & McKeown and Gibson & 1951 \\
\hline Litter Size & Negative & McKeown and Record & 1954 \\
\hline Sex of Infant & Male $>$ Female & Karn and Penrose & 1951 \\
\hline Birth Rank of Infant & Positive & Karn and Penrose & 1951 \\
\hline Parental Race & $\begin{array}{l}\text { Complex } \\
\text { e.g. Indian < Caucasian } \\
\text { Negro < Caucasian }\end{array}$ & Hytten and Leitch & 1964 \\
\hline Maternal Age & Doubtful & Karn and Penrose & 1951 \\
\hline Maternal Socio-economic Status & Complex. Related to Stature & Gibson and McKeown & 1951 \\
\hline Maternal Stature & Positive & Cawley and others & 1954 \\
\hline Paternal Stature & Doubtful & Cawley and others & 1954 \\
\hline Maternal Weight & Positive & McKeown and Record & 1957 \\
\hline Maternal Weight Gain in Pregnancy & Positive & Hytten and Leitch & 1964 \\
\hline $\begin{array}{l}\text { Maternal Tobacco Smoking in } \\
\text { Pregnancy }\end{array}$ & Negative & Herriot, Billewicz, and Hytten & 1962 \\
\hline $\begin{array}{l}\text { Maternal } \\
\text { Disease }\end{array} \quad\left\{\begin{array}{l}\text { Hypertension } \\
\text { Diabetes }\end{array}\right.$ & $\begin{array}{l}\text { Negative } \\
\text { Positive }\end{array}$ & $\begin{array}{l}\text { Johnson } \\
\text { Miller, Hurwitz, and Kuder }\end{array}$ & $\begin{array}{l}1958 \\
1944\end{array}$ \\
\hline
\end{tabular}


Lambeth Hospital in south-east London, one third of all mothers confined between 1958 and 1960 were immigrants. All deliveries in this period have been retrospectively surveyed to compare the obstetric behaviour of immigrant mothers with that of the indigenous population. The main findings have been reported elsewhere (Barron and Vessey, 1966), but the present report is concerned with a more detailed analysis of the data on birth weight.

\section{Data Analysed}

Of the 6,025 infants born at Lambeth Hospital during the years $1958-60$, only those born to mothers from Great Britain, Ireland, the West Indies, or Cyprus have been studied. No information concerning the nationality of the father was available.

The composition of the sample is shown in Table II. For each of the 5,283 infants studied, birth rank, maternal age, maternal social class (Registrar General's classification-see Barron and Vessey, 1966), and maternal height were known. There was also some information about the duration of gestation for all but twenty infants, but these data were regarded as potentially unreliable (see McKeown and Gibson, 1952).

TABLE II

COMPOSITION OF THE SAMPLE

\begin{tabular}{|c|c|c|c|}
\hline \multicolumn{2}{|l|}{ Infants Excluded } & \multicolumn{2}{|l|}{ Infants Included } \\
\hline Reason & No. & Nationality & No. \\
\hline $\begin{array}{l}\text { Plural pregnancies } \\
\text { Perinatal deaths } \\
\text { Maternal height unknown } \\
\text { Birth weight unknown } \\
\text { Miscellaneous nationalities }\end{array}$ & $\begin{array}{r}132 \\
182 \\
150 \\
10 \\
268\end{array}$ & $\begin{array}{l}\text { British } \\
\text { Irish } \\
\text { West Indian } \\
\text { Cypriot }\end{array}$ & $\begin{array}{r}3,656 \\
636 \\
833 \\
158\end{array}$ \\
\hline Total & 742 & Total & 5,283 \\
\hline
\end{tabular}

On abstraction from the case notes, the data on birth weight had been coded in the form of $1 \mathrm{lb}$. groups save for one group which spanned $1 \frac{1}{2} \mathrm{lb}$.

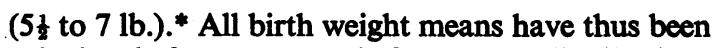
calculated from grouped frequency distributions employing the mid-point as the representative value for each group.

\section{RESUlts}

Preliminary study showed that infants born to Barbadian women were on average $0.24 \mathrm{lb}$. heavier than infants born to other West Indian women, almost all of whom came from Jamaica. The numbers of infants born to Barbadian and Cypriot women were too few for detailed study, so the major part of the analysis relates only to British, Irish, and Jamaican infants. Of these, the Irish infants had the highest mean birth weight $(7 \cdot 32 \mathrm{lb}$.) and the Jamaican infants the lowest $(6.98 \mathrm{lb}$.) with the British ones in between $(7 \cdot 17 \mathrm{lb}$.).

\section{INFANT SEX}

The infant sex difference (male minus female) in mean birth weight was $\mathbf{0 . 1 8} \mathrm{lb}$. for Irish, $\mathbf{0 . 2 5} \mathrm{lb}$. for British, and $\mathbf{0 . 3 0} \mathrm{lb}$. for Jamaican infants. Since the sex ratio in all subclasses approximated to unity, no further account has been taken of infant sex in the analysis of nationality differences in birth weight.

\section{Social Class}

It is shown in Table III that among British infants those from Social Classes I and II were on average about $0.25 \mathrm{lb}$. heavier than those from thece other social classes. No reasonable social class com-? parison was possible for the other nationality groups, since there were only 26 Irish and 29 Jamaican women from the two highest social classes. Infants from Social Classes I and II have therefore been omitted from all further comparisons. The effect of this exclusion is seen from the last row of Table III to eliminate about 10 per cent. of the difference in mean birth weight between the British and Jamaican infants.

* This was done to enable prematurity rates to be read directly from the punched cards for the original analysis.

TABLE III

MEAN INFANT BIRTH WEIGHT IN RELATION TO MATERNAL NATIONALITY AND SOCIAL CLASS

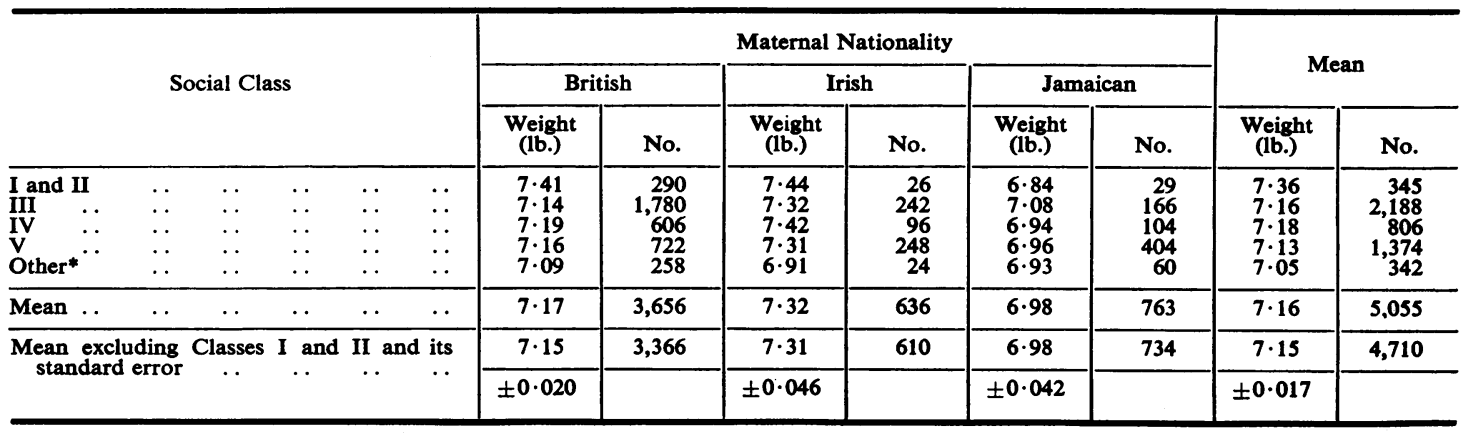


Maternal Age and Birth Rank

The apparent increase in mean birth weight with maternal age shown in Table IV largely reflects the influence of increasing birth rank. This finding agrees with that of many other authors (e.g. Martin, 1931; Karn and Penrose, 1951; McKeown and Gibson, 1951; Abolins, 1961). The expected marginal means in Table IV represent the predicted values if the bias due to disproportionate weighting of the cells of the Table had been removed. The associated nonorthogonal analysis of variance indicates that the increase in mean birth weight with increasing birth rank is highly significant, whereas the effects of age and the age-birth rank interaction are not significant. Studies within each of the three major nationality groups produced similar results, although the amount of data for the Irish and Jamaican infants was rather small. It was concluded that maternal age could be discounted in subsequent comparisons.

\section{Maternal Height and BiRTh RaNk}

Fig. 1 (overleaf) shows that the overall relationship between mean birth weight and maternal height was linear. The size of the regression coefficient $(0.0806$ lb. per inch) is similar to that calculated from data given by Cawley, McKeown, and Record (1954) for births in Birmingham. Within the nationality groups (Table V) the slope of the regression line was greater for the British infants $(0.0894 \mathrm{lb}$. per in.) than for the Irish $(0.0689 \mathrm{lb}$. per in.) or for the Jamaican infants $(0.0600 \mathrm{lb}$. per in.), but tests of significance show that this degree of variation in the coefficients can be ascribed to chance.

TABLE IV

MEAN INFANT BIRTH WEIGHT (lb.) IN RELATION TO BIRTH RANK AND MATERNAL AGE

(Means based on less than 100 observations omitted)

\begin{tabular}{|c|c|c|c|c|c|c|c|c|c|}
\hline \multirow{2}{*}{\multicolumn{3}{|c|}{ Birth Rank }} & \multicolumn{5}{|c|}{ Maternal Age (yrs) } & \multirow{2}{*}{$\begin{array}{l}\text { Weighted } \\
\text { Mean }\end{array}$} & \multirow{2}{*}{$\begin{array}{l}\text { Expected } \\
\text { Mean }\end{array}$} \\
\hline & & & $\leqslant 19$ & $20-24$ & $25-29$ & $30-34$ & $35+$ & & \\
\hline 1st born & .. & .. & $6 \cdot 93$ & $7 \cdot 00$ & $7 \cdot 02$ & $6 \cdot 77$ & - & 6.97 & 6.98 \\
\hline 2nd born & .. & .. & $6 \cdot 98$ & $7 \cdot 29$ & $7 \cdot 17$ & $7 \cdot 20$ & - & $7 \cdot 22$ & $7 \cdot 21$ \\
\hline 3rd born & .. & .. & 一 & $7 \cdot 15$ & $7 \cdot 21$ & $7 \cdot 33$ & $7 \cdot 23$ & $7 \cdot 22$ & $7 \cdot 20$ \\
\hline \multicolumn{2}{|c|}{ 4th and later born } & .. & 一 & 一 & $7 \cdot 37$ & $7 \cdot 28$ & $7 \cdot 41$ & $7 \cdot 32$ & $7 \cdot 30$ \\
\hline \multicolumn{2}{|c|}{ Weighted Mean } & .. & 6.94 & $7 \cdot 12$ & $7 \cdot 18$ & $7 \cdot 19$ & $7 \cdot 31$ & $7 \cdot 15$ & \\
\hline \multicolumn{2}{|c|}{ Expected Mean } & $\ldots$ & $7 \cdot 05$ & $7 \cdot 16$ & $7 \cdot 15$ & $7 \cdot 13$ & $7 \cdot 22$ & & \\
\hline
\end{tabular}

ANALYSIS OF VARIANCE FOR TABLE IV

\begin{tabular}{|c|c|c|c|c|c|c|c|c|c|}
\hline \multicolumn{5}{|c|}{ Source of Variation } & D.F. & Sums of Squares & Mean Squares & Variance Ratios & P Values \\
\hline $\begin{array}{l}\text { Birth rank } \\
\text { Age . } \\
\text { Birth rank } \\
\text { Residual }\end{array}$ & $\begin{array}{l}\ddot{x} \text { Age } \\
\cdots\end{array}$ & $\begin{array}{l}\ddot{*} \\
\cdots\end{array}$ & $\begin{array}{l}\cdots \\
\cdots \\
\cdots\end{array}$ & $\begin{array}{l}\cdots \\
\cdots \\
\cdots\end{array}$ & $\begin{array}{r}3 \\
4 \\
12 \\
4,690\end{array}$ & $\begin{array}{r}56 \cdot 81 \\
7 \cdot 43 \\
22 \cdot 72 \\
6022 \cdot 68\end{array}$ & $\begin{array}{r}18 \cdot 94 \\
1 \cdot 86 \\
1 \cdot 89 \\
1 \cdot 28\end{array}$ & $\begin{array}{r}14 \cdot 80 \\
1 \cdot 45 \\
1 \cdot 48\end{array}$ & $\begin{array}{c}\mathbf{P}<0.001 \\
\mathbf{P}>0.20 \\
0.20>\mathbf{P}>0.05\end{array}$ \\
\hline Total & . & $\cdots$ & $\cdots$ & $\cdots$ & 4,709 & $6142 \cdot 4$ & & & \\
\hline
\end{tabular}

Note: Data omitted from Table IV have been included in the analysis of variance.

TABLE V

MEAN INFANT BIRTH WEIGHT IN RELATION TO MATERNAL HEIGHT AND NATIONALITY

\begin{tabular}{|c|c|c|c|c|c|c|c|c|}
\hline \multirow{3}{*}{ Maternal Height (in.) } & \multicolumn{6}{|c|}{ Maternal Nationality } & \multirow{3}{*}{\multicolumn{2}{|c|}{ Mean }} \\
\hline & \multicolumn{2}{|c|}{ British } & \multicolumn{2}{|c|}{ Irish } & \multicolumn{2}{|c|}{ Jamaican } & & \\
\hline & Weight (lb.) & No. & Weight (lb.) & No. & Weight (lb.) & No. & & \\
\hline $\begin{array}{c}\leqslant 59 \\
60 \\
61 \\
62 \\
63 \\
64 \\
65+\end{array}$ & $\begin{array}{l}6 \cdot 72 \\
6 \cdot 89 \\
7 \cdot 15 \\
7 \cdot 10 \\
7 \cdot 22 \\
7 \cdot 22 \\
7 \cdot 49\end{array}$ & $\begin{array}{l}307 \\
366 \\
534 \\
599 \\
526 \\
449 \\
585\end{array}$ & $\begin{array}{l}7 \cdot 16 \\
7 \cdot 07 \\
7 \cdot 28 \\
7 \cdot 35 \\
7 \cdot 16 \\
7 \cdot 73 \\
7 \cdot 54\end{array}$ & $\begin{array}{r}80 \\
75 \\
130 \\
118 \\
77 \\
62 \\
68\end{array}$ & $\begin{array}{l}6 \cdot 67 \\
6 \cdot 86 \\
6 \cdot 83 \\
7 \cdot 03 \\
7 \cdot 17 \\
7 \cdot 19 \\
7 \cdot 07\end{array}$ & $\begin{array}{r}90 \\
78 \\
113 \\
153 \\
116 \\
85 \\
99\end{array}$ & $\begin{array}{l}6 \cdot 79 \\
6 \cdot 91 \\
7 \cdot 12 \\
7 \cdot 12 \\
7 \cdot 20 \\
7 \cdot 27 \\
7 \cdot 44\end{array}$ & $\begin{array}{l}477 \\
519 \\
777 \\
870 \\
719 \\
596 \\
752\end{array}$ \\
\hline $\begin{array}{l}\text { Regression Coefficient } \\
\text { (weight on height) }\end{array}$ & \multicolumn{2}{|c|}{$\begin{array}{r}0.0894 \\
\pm 0.0085\end{array}$} & \multicolumn{2}{|c|}{$\begin{array}{r}0.0689 \\
\pm 0.0210\end{array}$} & \multicolumn{2}{|c|}{$\begin{array}{r}0.0600 \\
\pm 0.0163\end{array}$} & \multicolumn{2}{|c|}{$\begin{array}{r}0.0806 \\
\pm 0.0071\end{array}$} \\
\hline
\end{tabular}




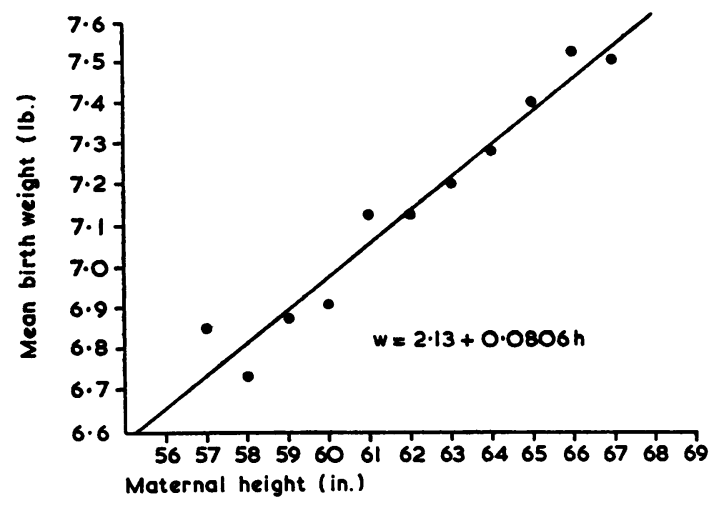

FIG. 1.-Relationship between mean birth weight and maternal height. Only means based on at least 100 observations have been entered on the diagram. The calculation of the regression line was based on all observations.

There was no evidence that the regression of birth weight on maternal height was more marked for the first born than for the later born infants, as suggested by McKeown and Record (1954). On the contrary, there was a small increase in the size of the regression coefficients from $0.0710 \pm 0.0116 \mathrm{lb}$. per in. for first born to $0 \cdot 1095 \pm 0.0177 \mathrm{lb}$. per in. for fourth and later born infants.

Table VI shows that the nationality differences in mean birth weight were reasonably consistent within the different birth ranks, and that the British mothers were, on average, 0.30 in. taller than the Jamaican and 0.63 in. taller than the Irish mothers. Multiparae were also shorter than primiparae, especially among

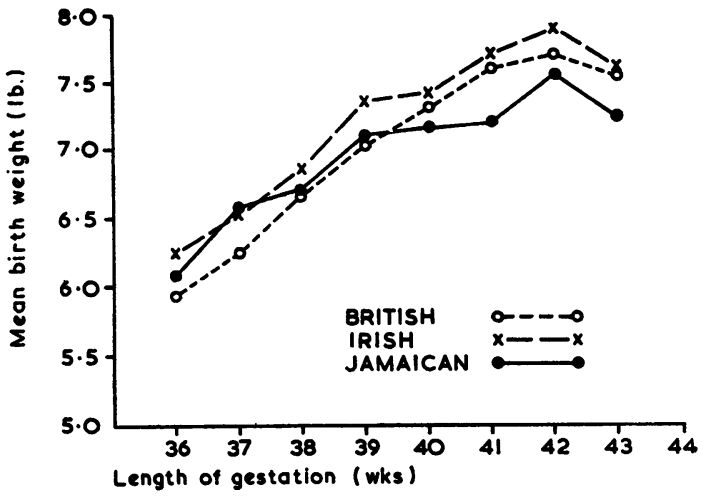

Fig. 2.-Nationality differences in relationship between mean birth weight and duration of gestation.

British mothers-probably an expression of the association between high parity and low socioeconomic status.

The comparison of the nationality birth weight means is thus biased by differences in maternal height. Since there was no significant variation in the regression coefficients of birth weight on maternal height within the different nationality and birth rank groups, an overall within-group regression coefficient was calculated and used to adjust the birth weight means to a constant maternal height. The effect is shown in Table VI to increase the difference between the British and Irish birth weight means, while slightly diminishing the difference between the

TABLE VI

MEAN INFANT BIRTH WEIGHT IN RELATION TO BIRTH RANK AND MATERNAL NATIONALITY MATERNAL HEIGHT MEANS ARE ALSO SHOWN FOR EACH SUBCLASS (Numbers of infants shown in parentheses)

\begin{tabular}{|c|c|c|c|c|c|c|c|}
\hline \multirow{2}{*}{ Birth Rank } & \multirow{2}{*}{\multicolumn{3}{|c|}{ Mean Weights and Heights }} & \multicolumn{3}{|c|}{ Maternal Nationality } & \multirow{2}{*}{ Mean } \\
\hline & & & & British & \multirow{2}{*}{$\frac{\text { Irish }}{7 \cdot 10(242)}$} & \multirow{2}{*}{\begin{tabular}{r|} 
Jamaican \\
$\begin{array}{r}6 \cdot 82(125) \\
62 \cdot 24\end{array}$
\end{tabular}} & \\
\hline 1st born & $\begin{array}{l}\text { Mean birth weight (lb.) } \\
\text { Mean maternal height (in.) }\end{array}$ & $\cdots$ & $\cdots$ & $\begin{array}{r}6 \cdot 95 \\
62 \cdot 56\end{array}(1,305)$ & & & $\begin{array}{r}6 \cdot 97(1,672) \\
62 \cdot 44\end{array}$ \\
\hline & Adjusted birth weight $\ldots$ & $\ldots$ & $\ldots$ & $6 \cdot 92$ & $7 \cdot 13$ & $6 \cdot 82$ & $6 \cdot 94$ \\
\hline \multirow{2}{*}{$\begin{array}{l}\text { 2nd and } 3 r d \\
\text { born }\end{array}$} & $\begin{array}{l}\text { Mean birth weight (lb.) ... } \\
\text { Mean maternal height (in.) }\end{array}$ & 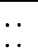 & $\cdots$ & $\begin{array}{r}7 \cdot 25(1,588) \\
62 \cdot 40\end{array}$ & $\begin{array}{r}7 \cdot 48(279) \\
61 \cdot 68\end{array}$ & $62 \cdot 86(347)$ & $\begin{array}{r}7 \cdot 22 \\
62 \cdot 25\end{array}(2,214)$ \\
\hline & Adjusted birth weight $\ldots$ & $\ldots$ & $\ldots$ & $7 \cdot 24$ & $7 \cdot 53$ & $6 \cdot 88$ & $7 \cdot 22$ \\
\hline \multirow{2}{*}{$\begin{array}{l}\text { 4th and later } \\
\text { born }\end{array}$} & $\begin{array}{l}\text { Mean birth weight (lb.) ... } \\
\text { Mean maternal height (in.) }\end{array}$ & $\begin{array}{l}\cdots \\
\cdots\end{array}$ & $\begin{array}{l}\ldots \\
\cdots\end{array}$ & $\begin{array}{r}7 \cdot 37(473) \\
61 \cdot 95\end{array}$ & $\begin{array}{r}7 \cdot 37(89) \\
61 \cdot 69\end{array}$ & $\begin{array}{r}7 \cdot 22(262) \\
62 \cdot 10\end{array}$ & $\begin{array}{r}7 \cdot 32(824) \\
61 \cdot 97\end{array}$ \\
\hline & Adjusted birth weight $\ldots$ & $\ldots$ & $\ldots$ & $7 \cdot 40$ & $7 \cdot 42$ & $7 \cdot 23$ & $7 \cdot 35$ \\
\hline \multirow[t]{2}{*}{ Mean } & $\begin{array}{l}\text { Mean birth weight (lb.) ... } \\
\text { Mean maternal height (in.) }\end{array}$ & $\begin{array}{l}\cdots \\
\cdots\end{array}$ & $\ddot{x}$ & $\begin{array}{r}7 \cdot 17(3,366) \\
62 \cdot 40\end{array}$ & $\begin{array}{r}7 \cdot 31(610) \\
61 \cdot 77\end{array}$ & $\begin{array}{r}6 \cdot 98(734) \\
62 \cdot 10\end{array}$ & $\begin{array}{r}7 \cdot 15(4,710) \\
62 \cdot 27\end{array}$ \\
\hline & Adjusted birth weight $\ldots$ & $\ldots$ & $\ldots$ & $7 \cdot 15$ & $7 \cdot 36$ & $6 \cdot 99$ & - \\
\hline
\end{tabular}

Notes: (1) Pooled within group estimate of regression of birth weight on maternal height $=0.0870 \pm 0.0070 \mathrm{lb}$. per in.

(2) Birth weight means adjusted to overall mean maternal height of $62 \cdot 27$ in. 
British and Jamaican means. The overall difference in mean birth weight between first born and later born infants is also increased.

\section{Gestation Length}

Comparison of the gestation length distribution with distributions studied by other workers (e.g. Karn, 1947; McKeown and Gibson, 1951) showed that there was an excess of gestation periods recorded as $\mathbf{4 0}$ weeks and a corresponding deficiency of those recorded as 39 and 41 weeks (Table VII). Otherwise, the present data were in reasonable agreement with those of other workers, and the overall mean duration of gestation was almost identical to that recorded by McKeown and Gibson (1951). The average length of gestation was, however, about 3 days less for the Jamaican patients than for the British or the Irish.

TABLE VII

PERCENTAGE DURATION OF GESTATION BY MATERNAL NATIONALITY

\begin{tabular}{|c|c|c|c|c|c|}
\hline \multirow{2}{*}{$\begin{array}{c}\text { Duration of } \\
\text { Gestation } \\
\text { (wks) }\end{array}$} & \multicolumn{4}{|c|}{ Maternal Nationality } & \multirow{2}{*}{$\begin{array}{c}\text { McKeown } \\
\text { and } \\
\text { Gibson* }\end{array}$} \\
\hline & British & Irish & Jamaican & Total & \\
\hline $\begin{array}{r}\leqslant 36 \\
37- \\
38- \\
39- \\
40- \\
41- \\
42- \\
43+\end{array}$ & $\begin{array}{r}4 \cdot 6 \\
3 \cdot 2 \\
8 \cdot 7 \\
14 \cdot 5 \\
42 \cdot 7 \\
14 \cdot 8 \\
8 \cdot 4 \\
3 \cdot 1\end{array}$ & $\begin{array}{r}4 \cdot 5 \\
4 \cdot 3 \\
7 \cdot 1 \\
14 \cdot 2 \\
40 \cdot 2 \\
16 \cdot 8 \\
8 \cdot 3 \\
4 \cdot 6\end{array}$ & $\begin{array}{r}4 \cdot 8 \\
6 \cdot 0 \\
14 \cdot 2 \\
19 \cdot 9 \\
39 \cdot 8 \\
8.6 \\
4 \cdot 1 \\
2.6\end{array}$ & $\begin{array}{r}4 \cdot 6 \\
3 \cdot 8 \\
9 \cdot 4 \\
15 \cdot 3 \\
41 \cdot 9 \\
14 \cdot 1 \\
7 \cdot 7 \\
3 \cdot 2\end{array}$ & $\begin{array}{r}5 \cdot 6 \\
4 \cdot 5 \\
8 \cdot 8 \\
20 \cdot 4 \\
28 \cdot 9 \\
18 \cdot 3 \\
8 \cdot 5 \\
5 \cdot 0\end{array}$ \\
\hline$\overline{\text { Total }}$ & $100 \cdot 0$ & $100 \cdot 0$ & $100 \cdot 0$ & $100 \cdot 0$ & $100 \cdot 0$ \\
\hline $\begin{array}{l}\text { Mean Length of } \\
\text { Gestation (days) }\end{array}$ & 278 & 279 & 275 & 278 & 278 \\
\hline
\end{tabular}

*McKeown and Gibson (1951). Data refer to live births only.

The relationship between mean birth weight and length of gestation is shown for each nationality group in Fig. 2 (see previous page). The negative correlation beyond 42 weeks is probably the result both of incorrect recollection and recording of dates and of the selection by the obstetricians of the larger infants for induced labour.

At all lengths of gestation the mean birth weight of the Irish infants was greater than that of the British, but the relationship between birth weight and gestation for the Jamaican infants was different from that for the other nationality groups. At 36 to 37 weeks' gestation the Jamaican infants were heavier than the British, but at 40 to 43 weeks the reverse was true. This relationship was consistent within all birth ranks where the numbers were sufficient for comparison.

There was no association between duration of gestation and birth rank, but on the average, women 64 in. tall or more had a gestation period about 2 days longer than women 60 in. tall or less (Table VIII). Approximate calculations suggest that only about 20 per cent. of the regression of birth weight on maternal height can be explained in terms of gestation length differences.

TABLE VIII

\begin{tabular}{|c|c|c|c|c|c|c|}
\hline \multirow{2}{*}{\multicolumn{4}{|c|}{ Maternal Nationality }} & \multicolumn{3}{|c|}{ Maternal Height (in.) } \\
\hline & & & & $\leqslant 60$ & $61-63$ & $64+$ \\
\hline British ... & .. & $\ldots$ & . & 277 & 278 & 279 \\
\hline Irish & .. & .. & .. & 277 & 278 & 281 \\
\hline Jamaican & .. & .. & .. & 275 & 275 & 276 \\
\hline Mean ... & . & $\ldots$ & .. & 277 & 278 & 279 \\
\hline
\end{tabular}

BIRTH WEIGHTS OF CYPRIOT AND BARBaDIAN INFANTS

Cypriot women were, on the average, only 59.5 in. tall and gave birth to infants of very low mean weight (6.88 lb.) (Table IX). If, as seems likely, the regression of birth weight on maternal height calculated for the other nationality groups can be applied to the Cypriots, then the expected mean birth weight of Cypriot infants born to mothers $62 \cdot 3$ in. tall would be $7 \cdot 12 \mathrm{lb}$. This value is very much the same as that for British infants $(7 \cdot 15 \mathrm{lb}$.) born to mothers of that height (Table VI).

\section{TABLE IX}

CYPRIOT AND BARBADIAN BIRTH WEIGHTS AND MATERNAL HEIGHTS, BY BIRTH RANK

\begin{tabular}{c|l|c|c}
\hline \multirow{3}{*}{ Birth rank } & Mean Weights and Heights & \multicolumn{2}{|c|}{ Maternal Nationality } \\
\cline { 2 - 4 } & & Cypriot & Barbadian \\
\hline \multirow{3}{*}{ 1st born } & $\begin{array}{l}\text { Mean birth weight (lb.) } \\
\text { Mean maternal height (in.) }\end{array}$ & $59 \cdot 68$ & $6 \cdot 87$ \\
& No. of observations & 55 & 17 \\
\hline 2nd and & Mean birth weight (lb.) & $6 \cdot 98$ & $7 \cdot 35$ \\
3rd born & Mean maternal height (in.) & $59 \cdot 14$ & $62 \cdot 31$ \\
& No. of observations & 80 & 35 \\
\hline 4th and & Mean birth weight (lb.) & $6 \cdot 97$ & $7 \cdot 31$ \\
later born & Mean maternal height (in.) & $59 \cdot 87$ & $62 \cdot 22$ \\
& No. of observations & 23 & 18 \\
\hline \multirow{2}{*}{ Mean } & Mean birth weight (lb.) & $6 \cdot 88$ & $7 \cdot 22$ \\
& Mean maternal height (in.) & $59 \cdot 46$ & $62 \cdot 26$ \\
& No. of observations & 158 & 70 \\
\hline
\end{tabular}

The Barbadian infants were $0 \cdot 24 \mathrm{lb}$. heavier than the Jamaican ones (Table IX), but the numbers were too few for detailed study. The Barbadian women were only fractionally taller than the Jamaican women, so the birth weight difference cannot be explained in terms of maternal height. 
Birth Weights of British INfants from Social Classes I and II

In Table III, it was shown that British infants from Social Classes I and II were about $0.25 \mathrm{lb}$. heavier on the average than British infants from the other social classes.

Table $\mathrm{X}$ (overleaf) shows that there was also a large class difference (about 1.5 in.) in mean maternal height. The regression of birth weight on maternal height was calculated for British Social Classes I and II and found to be closely similar to that for the other social classes $(b=0.0975 \pm 0.0265 \mathrm{lb}$./in. $)$. Correction of the birth weight means to a maternal height of $62.3 \mathrm{in}$. is seen from the last column of Table $\mathrm{X}$ to eliminate about 50 per cent. of the social class difference in birth weight.

The mean gestation period was identical in the two social class groups.

\section{Discussion}

An attempt has been made to compare the birth weight means for the nationality groups by assessing the factors already known to affect birth weight. Two such factors have been discounted-namely infant sex because both sexes were more or less equally represented in all comparisons, and maternal age because the apparent effect of this variable was shown largely to reflect the effect of birth rank. Obvious social class differences were eliminated by omitting infants from Social Classes I or II from the general analysis, the other social classes appearing to be reasonably homogeneous with respect to birth weight.

There was no evidence of significant nationality differences in the regression of birth weight on maternal height. After adjusting the birth weight means for height, there were still substantial nationality differences which were reasonably consistent within the different birth ranks.
Information on length of gestation has many shortcomings (McKeown and Gibson, 1952) and in the experience of one of us (S.L.B.) West Indian patients are particularly vague about their menstrual history. The present data suggest, however, that none of the differences in mean birth weight between the British and Irish infants can be explained in terms of gestation length. In the case of the Jamaican infants the relationship between mean birth weight and gestation length was different from that for the other nationality groups. This might be explained by the relatively greater inaccuracy of the Jamaican mothers in estimating the date of their last menstrual period, the effect of which would be to relatively decrease the apparent regression of birth weight on gestation length for that nationality group.

The relationship may, however, be genuinely different, the growth rate of the Jamaican infants perhaps slowing up more markedly near term than that of the British or Irish infants. Work on a very large scale in New York by Erhardt and others (1964) has shown that non-white infants when born before 30 weeks' gestation weigh more on the average than white, but less when born thereafter. A similar relationship holds for the present data, but the changeover occurs at 38 to 39 weeks' gestation.

The effect of gestation length on the difference in mean birth weight between the British and Jamaican infants is thus uncertain. If the true regression of birth weight on gestation length was similar for the two nationalities, the 3 days' shorter gestation period for the Jamaican infants would account for more than half of the difference in mean birth weight between the two groups.

There is some independent evidence that West Indian immigrants give birth to lighter infants than the British or Irish. Statistics for domiciliary births in the London area for the year 1961 (Gore, 1965) show a difference in mean birth weight of $0.39 \mathrm{lb}$.

TABLE X

MEAN INFANT BIRTH WEIGHT BY BIRTH RANK

A COMPARISON OF BRITISH SOCIAL CLASSES I AND II WITH OTHER BRITISH SOCIAL CLASSES (Numbers of infants shown in parentheses)

\begin{tabular}{|c|c|c|c|c|c|c|c|c|}
\hline \multirow{2}{*}{ Birth Rank } & \multirow{2}{*}{\multicolumn{5}{|c|}{ Mean Weights and Heights }} & \multicolumn{2}{|c|}{ Social Class } & \multirow{3}{*}{$\begin{array}{c}\text { Difference } \\
\begin{array}{c}0.32 \\
1.46\end{array}\end{array}$} \\
\hline & & & & & & I and II & III, IV, V, Other & \\
\hline \multirow[t]{2}{*}{ 1st born } & $\begin{array}{l}\text { Mean birth weight (lb.) } \\
\text { Mean maternal height (in.) }\end{array}$ & $\because$ & $\because$ & $\because$ & 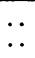 & $\begin{array}{r}7 \cdot 27(146) \\
64 \cdot 02\end{array}$ & $\begin{array}{r}6 \cdot 95 \\
62 \cdot 56\end{array}(1,305)$ & \\
\hline & Adjusted birth weight & $\ldots$ & $\ldots$ & .. & $\ldots$ & $7 \cdot 12$ & 6.92 & $0 \cdot 20$ \\
\hline \multirow[t]{2}{*}{ 2nd and 3rd born } & $\begin{array}{l}\text { Mean birth weight (lb.) } \\
\text { Mean maternal height (in.) }\end{array}$ & $\ldots$ & 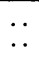 & $\because$ & $\because$ & $\begin{array}{r}7 \cdot 52(130) \\
64 \cdot 03\end{array}$ & $\begin{array}{r}7 \cdot 25 \\
62 \cdot 40\end{array}$ & $\begin{array}{l}0 \cdot 27 \\
1 \cdot 63\end{array}$ \\
\hline & Adjusted birth weight & .. & .. & .. & .. & $7 \cdot 37$ & $7 \cdot 24$ & 0.13 \\
\hline
\end{tabular}


between West Indian infants on the one hand and British and Irish infants on the other (Table XI). The corresponding difference for the present survey was $0.21 \mathrm{lb}$.

TABLE XI

MEAN INFANT BIRTH WEIGHT BY MATERNAL NATIONALITY AND BIRTH RANK

\begin{tabular}{|c|c|c|c|c|c|c|}
\hline \multirow{3}{*}{ Birth Rank } & \multicolumn{4}{|c|}{$\begin{array}{l}\text { Mother's Country of } \\
\text { Upbringing }\end{array}$} & \multirow{2}{*}{\multicolumn{2}{|c|}{ Mean }} \\
\hline & \multicolumn{2}{|c|}{ United Kingdom } & \multicolumn{2}{|c|}{ West Indies } & & \\
\hline & $\begin{array}{c}\text { Weight } \\
\text { (lb.) }\end{array}$ & No. & $\begin{array}{l}\text { Weight } \\
\text { (lb.) }\end{array}$ & No. & $\begin{array}{c}\text { Weight } \\
\text { (lb.) }\end{array}$ & No. \\
\hline First born & $7 \cdot 33$ & 647 & $6 \cdot 72$ & 13 & $7 \cdot 32$ & $\overline{660}$ \\
\hline 2nd and 3 rd born & $7 \cdot 51$ & 6,032 & $6 \cdot 99$ & 171 & $7 \cdot 50$ & 6,203 \\
\hline 4th and later born & $7 \cdot 53$ & 2,807 & $7 \cdot 26$ & 170 & $7 \cdot 52$ & 2,977 \\
\hline Mean & $7 \cdot 50$ & $\overline{9,486}$ & $7 \cdot 11$ & 354 & $7 \cdot 49$ & $\overline{9,840}$ \\
\hline
\end{tabular}

Figures supplied by Mr A. T. Gore.

An important factor which might have a bearing on the nationality differences in mean birth weight is maternal body weight. McKeown and Record (1957) provide data which indicate that the regression of infant birth weight on maternal body weight adjusted for height is very approximately $0.02 \mathrm{lb}$./lb. Data on maternal body weight at 20 weeks' gestation was recorded for about half the patients in the present study, but only on Powers-Samas cards. Detailed study was considered impracticable, but a simple analysis showed that the regression of maternal body weight on maternal height was approximately linear ( $b=4.0 \mathrm{lb}$./in.), and that at each height the West Indian patients weighed about $4.5 \mathrm{lb}$. more, and the Irish patients about $2.0 \mathrm{lb}$. more than the British. If a similar relationship to that found by McKeown and Record holds for the present data and if the apparent effect of maternal body weight corrected for height is independent of the other factors studied, then the difference in mean birth weight between Irish and British infants is reduced by about $0.04 \mathrm{lb}$. by allowance for the nationality difference in maternal body weight, while the difference between the British and Jamaican infants is increased by about $0 \cdot 10 \mathrm{lb}$.

A further factor briefly considered was the habit of cigarette smoking which is associated with a less than average birth weight (Herriot, Billewicz, and Hytten, 1962). A small independent survey was conducted on 159 patients, of whom 44 (27 per cent.) were West Indian. It showed that cigarette smoking was much less prevalent among West Indian than British patients.

Our overall conclusion, therefore, is that there are differences in mean weight of birth of infants born to mothers originating in different countries which cannot completely be accounted for by any of the factors known to be associated with birth weight which were also recorded in the present study.

\section{SUMMARY}

The birth weights of 3,656 British, 636 Irish, 833 West Indian, and 158 Cypriot infants born at Lambeth Hospital in the years 1958-60 have been compared. Maternal country of origin was taken to indicate the nationality of the infant.

On the average, the Irish infants were the heaviest $(7.32 \mathrm{lb}$.) and the Cypriot infants the lightest (6.88 lb.). The mean birth weight of the British infants was $7.17 \mathrm{lb}$., of the Jamaican infants $6.98 \mathrm{lb}$., and of the Barbadian infants $7 \cdot 22 \mathrm{lb}$.

The differences between the birth weight means of the British, Irish, and Jamaican infants were not explained by nationality differences in social class, birth rank distribution, maternal height and weight, or duration of gestation. Information concerning duration of gestation was, however, rather inaccurate and that concerning maternal body weight was very incomplete.

We should like to express our thanks to the many people who have helped with this work and especially to the Director, Mr P. Payne, and Miss M. Martin and her staff of the South Metropolitan Cancer Registry who did much of the data processing; to Mrs A. Moulton and Mrs M. Thomas who so painstakingly abstracted the case notes; to Mr Hammond and his staff of the medical records department at Lambeth Hospital; and to Mrs A. Vessey for secretarial assistance.

We are grateful to Miss L. Hurter and Mr (now Professor) Philip Rhodes for permission to study their patients and to Prof. Rhodes for his help and encouragement in the initiation of the study. Prof. Sir Dugald Baird and his colleagues of the Obstetric Research Unit (M.R.C.) and Prof. R. Illsley of the Department of Sociology at Aberdeen have given much advice and encouragement.

The facilities for much of the analysis were made available through the kindness of Dr F. Yates, F.R.S., head of the Department of Statistics, Rothamsted Experimental Station.

Financial assistance for the survey and analysis was provided by the Regional Research Committees of the South West, and later, by the North East Metropolitan Regional Hospital Boards.

\section{REFERENCES}

Abolins, J. A. (1961). Acta obstet. gynec. scand., 40, 339. Achar, S. T., and Yankauer, A. (1962). Indian J. Child Hlth, 11, 157.

Barron, S. L., and Vessey, M. P. (1966). Brit. med. J., $1,1189$.

Cawley, R. H., Mckeown, T., and Record, R. G. (1954). Amer. J. hum. Genet., 6, 448.

Cone, T. E. (1961). Pediatrics, 28, 490. 
Connor, A., Bennett, C. G., and Louis, L. S. (1957). Hawaii med.J., 16, 626.

Erhardt, C. L., Joshi, G. B., Nelson, F. G., Kroll, B. H., and Weiner, L. (1964). Amer. J. publ. Hith, 54, 1841.

Gibson, J. R., and Mckeown, T. (1951). Brit. J. soc. Med., 5, 259.

Gore, A. T. (1965). Personal communication.

Herriot, A., Billewicz, W. Z., and Hytten, F. E. (1962). Lancet, 1, 771.

Hytten, F. E., and Leitch, I. (1964). "The Physiology of Human Pregnancy." Blackwell, Oxford.

Johnson, G. T. (1958). In "A Symposium on Nontoxaemic Hypertension in Pregnancy," ed. N. F. Morris, and J. C. McC. Browne, p. 66. Churchill, London.

Karn, M. N. (1947). Ann. Eugen. (Lond.), 14, 44. and Penrose, L. S. (1951). Ibid., 16, 147.

Lee, C. C. (1948). Chin. med. J., 66, 153.
Llewellyn-Jones, D. (1955). J. Obstet. Gynaec. Brit. Emp., $62,275$.

McKeown, T., and Gibson, J. R. (1951). Brit. J. soc. Med., 5, 98 .

(1952). Brit. med. J., 1, 938. 457.

and Record, R. G. (1954). Amer. J. hum. Genet., 6,

Martin, W. J. (1931). Ann. Eugen. (Camb.), 4, 327.

Meredith, H. V. (1952). Hum. Biol., 24, 290.

Miller, H. C., Hurwitz, D., and Kuder, K. (1944). J. Amer. med. Ass., 124, 271.

Rajoo, T. D., and Naidu, P. M. (1944). Indian med. Gaz., 79, 373.

Salber, E. J., and Bradshaw, E. S. (1951). Brit. J. soc. Med., 5, 113.

Shaw, M. M. (1933). E. Afr. med. J., 10, 32.

Uttley, K. H. (1940). Chin. med. J., 58, 582. 